\title{
Mateusz Krawczyk
}

Independent scholar

ORCID: 0000-0003-2035-487X

\section{The Paradox of Purity: Interpretation and Theological Implications of the Words k $\alpha \theta \alpha \rho$ ós

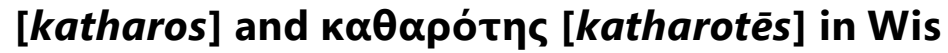 7:22-281}

Abstract: The double use of the word with the $\kappa \alpha \theta \alpha \rho$ root in the text of Wis 7:22-28 may set the interpretative direction for the discussion of the whole pericope. The exegesis of the pericope in the key of purity shows the following possibility of understanding the text: the moral aspect of purity of Wisdom can be imparted by it to pure people. A contradiction (paradox) in the text which concerns the subject of purity is observed: purity is, on the one hand, a condition, on the other, an effect of Wisdom's imparting action. A look at the further context of pericope Wis 7:22-28 (in particular Wis 9 and Wis 10) can lead to a probable solution to this potential contradiction: it lies in the idea of being elected by God, which anticipates human action.

Keywords: purity, cleanness, God's election, Book of Wisdom, Wis 7:22-28

Te Book of Wisdom can be called a literary work "from the 1 borderland" - of the Old and New Testaments, Jewish and Hellenic culture, monotheistic thought of Israel and Gentile polytheism. Written on the narrow borderline of times, cultures, and

\footnotetext{
1 This article is a revised and updated version of the previous study published in Polish: Mateusz Krawczyk, "Paradoks czystości. Interpretacja oraz implikacje

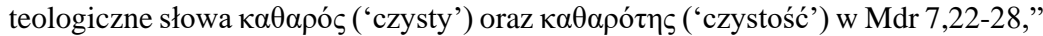
Collectanea Theologica 86 (2016) no. 1, 5-24. Translated from Polish by Maciej Górnicki.
} 
religions, it is a text that is extremely interesting and important even for those Christian traditions that consider it to be part of apocrypha. The description of Wisdom, which the author incorporates into Chapter 7 of his book, has been commented on and discussed many times in various ways, but in Polish literature there has been no attempt to approach it from the perspective of purity.

This article aims to undertake the exegesis of the fragment of Wis 7:22-28 precisely in such a key - in the perspective of its double use of a word referring directly to purity: $\kappa \alpha \theta \alpha \rho$ ó $\varsigma$ (pure) and $\kappa \alpha \theta \alpha \rho$ ó $\rceil\rceil \varsigma$ (purity). The first part of the article focuses on a lexicographic analysis of the word $\kappa \alpha \theta \alpha \rho$ ó $\varsigma$ and on indicating elements of the cultural and religious context of the time concerning the use of the term. Based on this short review of the most important dictionaries and lexicons, it will be possible in the next part to undertake a detailed exegesis of the text of Wis 7:22-28.

The fundamental academic problem addressed in the article is an attempt to propose a solution to the observed "paradox of purity," i.e., the following contradiction inside the pericope: purity as a condition of access to Wisdom and, at the same time, the effect of its action on man.

\section{Lexicographic Analysis and Cultural and Religious Context of the Words $\kappa \alpha \theta \alpha \rho o ́ s$ and $\kappa \alpha \theta \alpha \rho o ́ \tau n s$}

One of the most important Greek lexicons, A Greek-English Lexicon of Henry George Liddell and Robert Scott, lists a number of meanings and contexts for the word $\kappa \alpha \theta \alpha \rho$ ó $\varsigma$ in ancient Greek literature preserved to this day. Among the most important ones are first of all pureness in the sense of (a) physical purity, absence of flaws; (b) purity from admixtures, especially in relation to water, metals, also bread (as an adjective used in this context means white bread) or sound; the other relevant meanings are (c) purity in the spatial sense as an open area, a road or, in the context of the earth, as being free from weeds; (d) purity of language, also in the sense of simplicity and clarity of expression; (e) in relation to the army, flawless, a solid part of the army; (f) honesty, fairness, in a collocation: with clean hands; finally, finally in the sense that 
in this article will occupy us most, although it is not dominant in ancient literature - $(\mathrm{g})$ moral purity. ${ }^{2}$

$\mathrm{K} \alpha \theta \alpha \rho$ ó $\varsigma$ appears in the last sense, which is important, in the Letter of Aristeas ${ }^{3}$ ( $2^{\text {nd }}$ century BC), whose place of origin and cultural context (Hellenistic Alexandria) is extremely close to the Book of Wisdom. ${ }^{4}$ It is worth quoting two more uses of the word

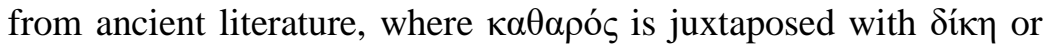

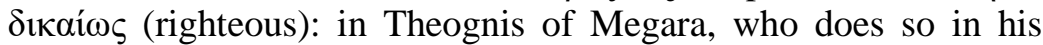
elegy, ${ }^{5}$ and in Demosthenes in his third speech against Philip of Macedonia (Third Philippics). ${ }^{6}$ The combination of the concepts of justice and purity, albeit in a slightly different sense from those of the classic authors mentioned, is important for the Old Testament texts; it will also have an important resonance in the text of the Book of Wisdom.

As far as the meaning of the word $\kappa \alpha \theta \alpha \rho$ ó $\varsigma$ is concerned which it assumes directly in the text of the Septuagint, to the Greek-English Lexicon by Liddell-Scott definitions quoted above, it is worth adding (h) purity [i.e., freedom, release] from oath (see Gen 24:8);

${ }^{2}$ Cf. $\kappa \alpha \theta \alpha \rho o ́ \varsigma$, in: H.G. Liddell, R. Scott, H.S. Jones, R. McKenzie, A GreekEnglish Lexicon: With a Revised Supplement (LSJ), 9th ed., Oxford 1996, 850-851. ${ }^{3}$ Or, as Polish scientific literature usually calls it, The Letter of Pseudo-Aristeas [List Pseudo-Arysteasza], also called The Letter of Aristeas to Philocrates.

${ }^{4}$ It is precisely about the wording: $\psi v \chi \tilde{\eta} \varsigma \kappa \alpha \theta \alpha \rho$ ó $\tau \eta \tau$ (derived from $\kappa \alpha \theta \alpha \rho o ́ \tau \eta \varsigma$ ) appearing in the text of the Letter of Pseudo-Aristeas, which was translated by M. Wojciechowski as "purity of the soul" ["duszy czystość"]. Cf. The Letter of PseudoAristeas, 234, Greek text after: http://www.ccel.org/ccel/swete/greekot.vii.ii.html (access 08.09.2015); for Polish translation see: M. Wojciechowski, "List PseudoArysteasza," Studia Theologica Varsaviensia 40 (2002) no. 1, 121-167.

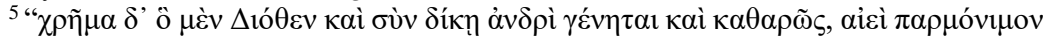

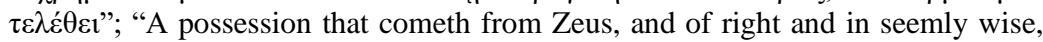
abideth evermore ...": Theognis, The Elegiac Poems, 197. Greek text and English translation after: http://www.perseus.tufts.edu/hopper/text?doc=Perseus\%3Atext \%3A2008.01.0479\%3Avolume\%3D1\%3Atext\%3D11\%3Asection\%3D2 (access 12.12.2020).

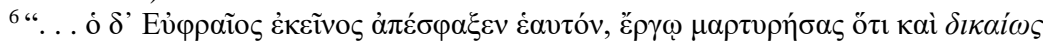

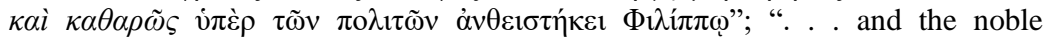
Euphraeus slew himself, giving thus a practical proof of the honesty and disinterested patriotism of his opposition to Philip": Demosthenes, Third Philippic, 19. Gr. text and En. transl. after: http://www.perseus.tufts.edu/hopper/text?doc= Perseus\%3Atext\%3A1999.01.0069\%3Aspeech\%3D9\%3Asection\%3D62\&highlig ht=kaqarw\%3Ds (access 12.12.2020). 
(i) purity of worship (i.e., the prayer of worship; see Tob 8:15); and emphasizing the use in the moral sense as purity of heart, innocence (see e.g. Gen 20:6). ${ }^{7}$ In similar meanings (pure; free from; innocent),

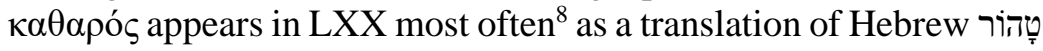
[țāhôr] and ז̛⿱ [zākāh]].

After the presentation of a general outline of the use and meaning of the word $\kappa \alpha \theta \alpha \rho$ ó $\varsigma$ and its derivatives, it is also worth looking briefly at the broader historical and cultural context, which will enable a better interpretation of the meaning in which the author of the Book of Wisdom uses the term. In the Theological Dictionary of the New Testament, Friedrich Hauck draws attention to the use of $\kappa \alpha \theta \alpha \rho$ ó $\zeta$ in the context of worship already in relation to "primitive religions," as he puts it, where purity and impurity - understood in part physically - are the starting point for moral content and are related to the concept of holiness. This is also the direction which Greek religions take, in which approaching the gods is only possible in a state of cultic purity. However, not only is ritual purity required, but moral one, as well. The writings of the Old Testament provide a similar general outline of development, but there the emphasis is on the holiness of God. ${ }^{9}$ Therefore the concept of ritual purity, developing and shaping cleansing activities as a condition of access to God, takes on the meaning of moral purity, which is implied by the awareness of the highest holiness. ${ }^{10}$ The combination of purity with the idea of holiness is all the more distinctive in the Old Testament because the verb root relating to the latter - קדש [qdš] can, in conjugations Pi'el and Hitpa ${ }^{\circ}$ el, be used in the sense: to purify. ${ }^{11}$ The Old Testament direction of understanding the word

${ }^{7}$ Cf. $\kappa \alpha \theta \alpha \rho o ́ \varsigma$, in: J. Lust, E. Eynikel, K. Hauspie, Greek-English Lexicon of the Septuagint, Revised ed. (LEH), Stuttgart 2003, BibleWorks, v. 9.

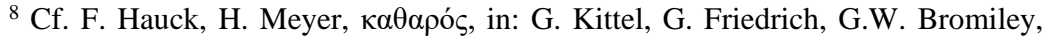
Theological Dictionary of the New Testament. Abridged (TDNT), Grand Rapids $1985,381$.

9 "Dieu étant la sainteté par essence": H. Lesêtre, "Pureté", in: Dictionnaire de la Bible, vol. 5, red. L. Pirot, A. Robert, Paris 1957, 872-874.

${ }^{10} \mathrm{H}$. Lesêtre refers here to the texts of Leviticus 11:44a.45b: "For I am the Lord your God; consecrate yourselves therefore, and be holy, for I am holy"; "you shall therefore be holy, for I am holy!" (RSV). Cf. H. Lesêtre, Pureté, 872-874.

${ }^{11}$ Cf. D.P. Wright, "Unclean and clean (OT)," in: Anchor Bible Dictionary (AB), vol. 6, ed. D.N. Freedman, New York 1992, 729. 
is colourfully summarized by David P. Wright, the author of the entry Unclean and clean in The Anchor Bible Dictionary, where we read that the terminological boundaries of purity/impurity extend from holiness on the one hand to sin, guilt and justice on the other. ${ }^{12}$ In turn, justice, according to Old Testament theology, is the exact observance of the Law - so we can see the semantic closeness of purity, including the moral (not only ritualistic) one, and the laws contained in the Torah. On the one hand, purity and holiness seem to be identified to a certain extent, ${ }^{13}$ while on the other hand, the line between cultic and moral chastity - despite the inevitability of their mutual influence - is not completely blurred.

For the present reflection it is essential to mention the Hellenistic Judaism, in which the spiritual meaning of purity becomes much more important than the ritualistic conception, while the cleansing rituals, although not abandoned, will assume above all a symbolic meaning. Rabbinical Judaism will later take a somewhat similar line, and the New Testament and Christianity will push the idea of internal purity to even further limits, stating that all that matters is the purification of the heart, not rituals, ${ }^{14}$ and transforming the Old Testament characteristic of cultic/ritual chastity into ethical/ soteriological purity. ${ }^{15}$

Although the context of the Greek religions has already been mentioned above, it is worth returning once again to Hellenistic thought and to that on the threshold of Hellenism as an extremely important context for the creation of the Book of Wisdom. ${ }^{16}$ What we have in mind is precisely the writings of Plato, who in his Phaedo quotes the concept of posthumous purification ${ }^{17}$ from guilt and sins. This purification exhibits a very interesting characteristic, much

12 Cf. ibid.

${ }^{13}$ Cf. H. Lesêtre, "Pureté", 872-874.

${ }^{14}$ Cf. F. Hauck, H. Meyer, $\kappa \alpha \theta \alpha \rho o ́ \varsigma$, in: TDNT, 381-384.

${ }^{15}$ Cf. H. Hübner, "Unclean and clean (NT)," in: AB, 741-745.

${ }^{16} \mathrm{H}$. Hübner, the author of the entry "Unclean and clean (NT)" in Anchor Bible Dictionary, goes as far as writing that the NT should be treated directly as Hellenist writings. It seems that a similar thing should be said about the Book of Wisdom. Cf. H. Hübner, "Unclean and clean (NT)," 742.

${ }^{17}$ Plato uses a participle from the verb $\kappa \alpha \theta \alpha i \rho \omega, \kappa \alpha \theta \alpha \rho \tilde{\omega}$, so we do not go beyond the root $\kappa \alpha \theta \alpha \rho$ here. 
more oriented towards morality than the ritual itself, not because it is a condition for leaving the land of the underworld, but because, in the case of grave misconduct, it requires the forgiveness of those who the person has wronged during their lifetime. ${ }^{18}$ What is particularly interesting, in the context of Wis 7:22-28, it is that we can also find in the Athenian philosopher a number of references to wisdom (although defined by terms other than $\sigma o \varphi^{i} \alpha^{19}$ ) and purity, purification, where these terms are linked, sometimes very closely (e.g. purification by the "love of wisdom"20; wisdom as "certain purification" 21 ; wisdom in the pure state ${ }^{22}$; purity and wisdom as a condition of access to gods ${ }^{23}$ ).

With the awareness and a certain brief outline of the meanings that the word $\kappa \alpha \theta \alpha \rho$ ó $\varsigma$ takes on in both Greek classical literature, in the Old Testament text, in the Hellenistic translation of the Hebrew Bible and in the religious context of the time, it is now possible to

\footnotetext{
${ }^{18}$ Cf. Plato, Phaedo 113d-114b.

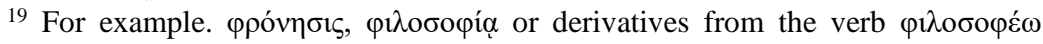
("love of wisdom").

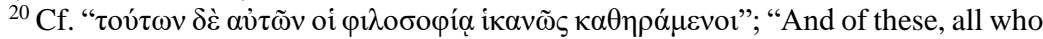
have duly purified themselves by philosophy live": Plato, Phaedo 114c. Gr. text and En. transl. after: http://www.perseus.tufts.edu/hopper/text?doc=plat.+phaedo +114 c (access 12.12.2020).

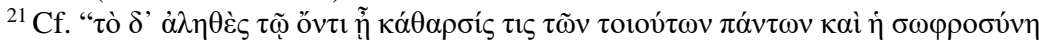

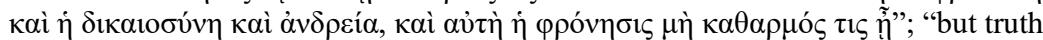
is in fact a purification from all these things, and self-restraint and justice and courage and wisdom itself are a kind of purification": Plato, Phaedo 69b-69c. Gr. text and En. transl. after: http://www.perseus.tufts.edu/hopper/ text?doc=Perseus\%3Atext\%3A1999.01.0170\%3Atext\%3DPhaedo\%3Asection\%3 D69b (access 12.12.2020).

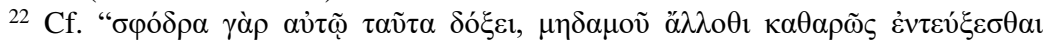

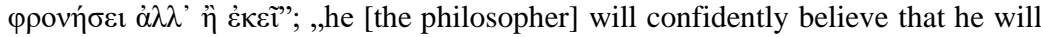
find pure wisdom nowhere else than in the other world.": Plato, Phaedo 68b, Gr. text and En. transl. after: http://www.perseus.tufts.edu/hopper/text?doc= Perseus\%3Atext\%3A1999.01.0170\%3Atext\%3DPhaedo\%3Asection\%3D68b (access 12.12.2020).

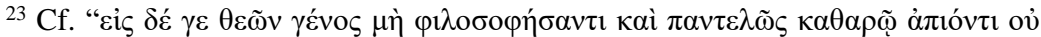

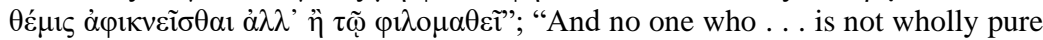
when he departs, is allowed to enter into the communion of the gods; but only the lover of knowledge"; Plato, Phaedo 82b-82c, Gr. text and En. transl. after: http://www.perseus.tufts.edu/hopper/text?doc=Perseus\%3Atext\%3A1999.01.0170 \%3Atext\%3DPhaedo\%3Asection\%3D82b (access 12.12.2020).
} 
move on to a detailed analysis of the double use of the term $\kappa \alpha \theta \alpha \rho$ ó $\varsigma$ in the text of Wis 7:22-28.

\section{Exegesis of Wis 7:22-28 Based on the Usage of Words With the Root $\kappa \alpha \theta \alpha \rho$ in Wis 7:23 and Wis 7:24}

\subsection{Determining the framework and indicating the usage of the words with the $\kappa \alpha \theta \alpha \rho$ root.}

Although the exact structure of the Book of Wisdom is a debated matter, the exegetes agree on the general division of the text into three parts - the book of eschatology, the book of wisdom and the book of history. ${ }^{24}$ The text of Wis 7:22[22b $]^{25}-28$, which is located within the second part, is usually included in a slightly longer part of the text - up to and including Wis 8:1 - and is referred to as a "description of Wisdom" (or "praise of Wisdom"26). For the purposes of this article, the text has been slightly shortened.

In the above pericope, the word with the root $\kappa \alpha \theta \alpha \rho$ appears twice: in verse 23 - pure ( $\kappa \alpha \theta \alpha \rho o ́ \varsigma)$ and in verse 24 - pure

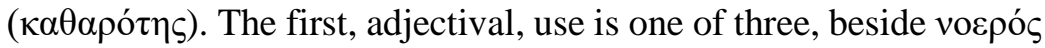
and $\lambda \varepsilon \pi \tau o \tau \alpha \tau$ ó $\varsigma$ - epithets of spirits. The second, noun use of the word refers to the way Wisdom works; it is therefore attributed to Wisdom herself.

\footnotetext{
${ }^{24}$ Cf. np. L.L. Grabbe, Wisdom of Solomon, Sheffield 1997, 18-23.

${ }^{25}$ In English literature, the beginning of a pericope is often described as v. $22 \mathrm{~b}$. However, this does not result from differences in the delimitation of the text, but only from different numbering of verses in some English-speaking translations of the Bible (e.g. New Revised Standard Version Bible [NRSV], New York 1989, BibleWorks, v. 9; Authorized Version Apocrypha, 1769 Blayney Edition [KJA], Oxford 1769, BibleWorks, v. 9.), where v. 22 starts a bit earlier, from the words that in the Polish translation of BT are presented in the following way: ,pouczyła mnie bowiem Mądrość - sprawczyni wszystkiego!" In this article the delineation of the Septuagint version by A. Rahlfs is used, which in this case is identical with the Polish BT.

${ }^{26}$ The literary genre of the entire Book of Wisdom is also often described as praise of Wisdom, i.e., an encomion, which is also reflected in the structure of the book. Cf. M. Gilbert, Mądrość Salomona, vol. 1, transl. S. Kobiałka, Kraków 2002, 7-11.
} 


\subsection{Purity in relation to man and to Wisdom}

To fathom the content and deeper meaning of the first use of the word $\kappa \alpha \theta \alpha \rho$ ó $\zeta$, one must first look at the beginning of the sentence that starts the pericope. The author, probably under the influence of Greek philosophy, ${ }^{27}$ attributes the features describing Wisdom -

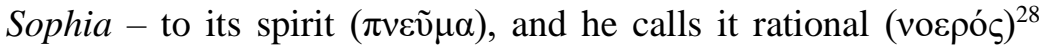
in the first place. Identical combination of words, followed by the term $\kappa \alpha \theta \alpha \rho$ ó $\zeta$, is found in the next part of the sentence with the only difference in the plural being used instead of singular:

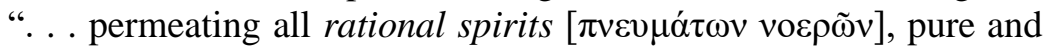
subtlest." This time it no longer refers to Wisdom, but to other beings. One must ask: can the second use apply to people? Providing a positive answer will allow the word $\kappa \alpha \theta \alpha \rho$ ó $\varsigma$ to be interpreted in relation to people as well, which will have theological implications for understanding the word in the pericope.

Eugène Osty authoritatively states that it is so: spirits can be understood as people; however, perhaps because of the character of his commentary, does not provide any arguments for this. ${ }^{29}$

Although from the many meanings of the word $\pi v \varepsilon \tilde{u} \mu \alpha$ in Septuagint and in the Book of Wisdom itself (wind, air - Wis 5:11; $13: 2 ; 17: 17$; air - Wis 5:23; 11:20; the breath of God as a witness of His power - Wis 11:20; the breath, the spirit giving life to the body, the human soul - Wis $2: 3 ; 5: 3 ; 15: 11 ; 15: 16 ; 16: 14$; the spiritual being, the spirits - Wis 7:20; the spirit of God - Wis 1:7; 12:1; $9: 17^{30}$ ) it seems that in verse 23 it first of all concerns spiritual

${ }^{27}$ In particular, of the Stoic and Platonic one. Cf. M. Gilbert, Madrość Salomona, vol. 1, 85-86; C. Larcher, Études su le livre de la Sagesse, Paris 1969, 369-375.

${ }^{28} \mathrm{C}$. Larcher even writes about the identification of Wisdom and Pneuma, which is the threshold for the New Testament pneumatology. Cf. C. Larcher, Etudes, 367.

${ }^{29}$ Cf. E. Osty, Le livre de la Sagesse (La Sainte Bible), Paris 1957, 59

${ }^{30}$ Together with the verse numbers a range of uses was given which appear in Wis. Greek-English Lexicon of the Septuagint also adds that the translation of the word $\pi v \varepsilon \tilde{v} \mu \alpha$, which refers to spiritual beings, may be used to refer to both good and bad

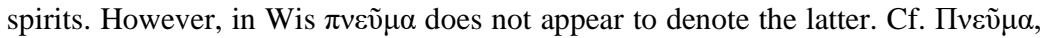
in: LEH; cf. also B. Poniży, Księga Mądrości. Od egzegezy do teologii, Poznań 2000, 183. 
beings, as B. Poniży ${ }^{31}$ and Chrysostome Larcher ${ }^{32}$ would have it, it is also possible to interpret it in the context of the human soul, as

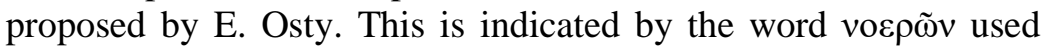
here, which - although it also appeared earlier with reference to Wisdom itself (v. 22) - is often combined with the human soul as the rational soul. ${ }^{33}$ Reading this passage in the context of humans would also be confirmed by the rest of the pericope: "Though she is but one, she can do all things, and while remaining in herself, she renews all things; in every generation she passes [in other words: enters]

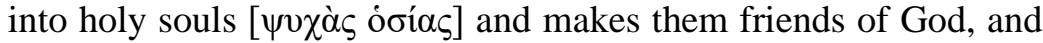
prophets." (RSVA) The common context and closeness of these verses suggest a connection between the "penetration of spirits" by Wisdom and her "passing/descending into the souls." Therefore,

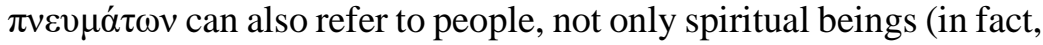
the Book of Wisdom uses, though not without some differences, $\pi v \varepsilon \tilde{u} \mu \alpha$ and $\psi v \chi \eta^{34}$ interchangeably to describe the human soul): it penetrates all spirits, including the souls of holy people.

The idea of sanctity, righteousness in the context of the abovementioned juxtaposition of penetration and descent, is here automatically referred to purity. This is confirmed by the lexicographic analysis presented above, especially with regard to the Old Testament background. One would like to say straight away, returning to the previous brief analysis of the possibility of the word

\footnotetext{
${ }^{31}$ Cf. B. Poniży, Księga Mądrości. Od egzegezy, 183.

${ }^{32}$ Cf. C. Larcher, Études, 373-374; idem, Le livre do la Sagesse ou la Sagesse de Salomon, vol. 2, Paris 1984, 491-492.

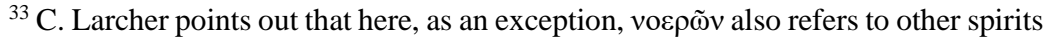
and beings, which only emphasises even more that the original meaning of the word is associated with the human soul. Cf. C. Larcher, Le livre de la Sagesse, vol. 2, 492.

${ }^{34} \mathrm{Cf}$. for example. Wis $16: 14$ or 15:8 and 15:16. C. Larcher, in an extensive and one of the most important studies of the Book of Wisdom, notes the specific

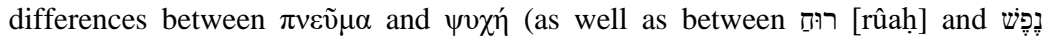
[nep̄eš] in the Hebrew Bible). In the Book of Wisdom, however, they come down to nuances rather than to significant and well-defined differences. The author writes: “. . . il $[\pi v \varepsilon \tilde{v} \mu \alpha]$ devient alors à peu près synonime de $\psi v \chi \eta ́$, et cette identification pratique était facilitée par différentes conceptions grecques et bibliques"; referring, among other things, to Greek philosophy, where - in addition to the awarding of the word $\pi v \varepsilon \tilde{v} \mu \alpha$ a central place in Stoic anthropology - a similar assimilation of terms took place. Cf. C. Larcher, Études, 263-264.
} 
$\pi v \varepsilon v \mu \alpha ́ \tau \omega \nu$ being applied to a human being, that Wisdom penetrates those of rational spirits that are pure - as it has been noted, $\kappa \alpha \theta \alpha \rho \tilde{\omega} v$

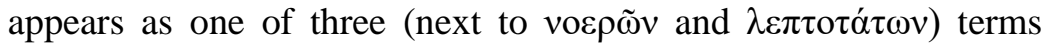
describing spirits. However, this first impression must be confronted with a more detailed interpretation of the text. When we look into its content, it is not difficult to come to the conclusion that we are dealing here with a certain gradation of "spirits," in order to show Wisdom in the next verse as superior to all of them ${ }^{35}$ - the pure

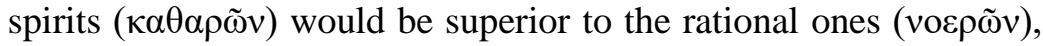
and both would give way to the most subtle in the hierarchy $(\lambda \varepsilon \pi \tau 0 \tau \alpha \dot{\tau} \omega \nu)$.

In this way, we smoothly move on to the next sentence of the pericope, with the word $\kappa \alpha \theta \alpha \rho$ ó $\rceil_{\varsigma}$ of particular interest to us there. Verse 24 ("For wisdom is more mobile than any motion; because of her pureness she pervades and penetrates all things") seems to continue the gradation from the previous verse: Wisdom is placed above all spirits, even the most subtle ones. In this way, by showing purity as a peculiar principle of all Sophia's actions, it is shown as distinct from the material world, belonging to the same sphere as the personal and transcendent God. ${ }^{36}$ It is to her intimate relationship with Him that she owes her nature, and therefore purity. ${ }^{37}$ It should be noted here that purity (in connotation with holiness) as a divine attribute also becomes an attribute of Wisdom ${ }^{38}$; it is through it that

${ }^{35}$ Cf. for example, idem, Le livre de la Sagesse, vol. 2, 491, 495.

${ }^{36}$ In the opinion of many exegetes, demonstrating the difference from the material world is the basic task of the whole catalogue of Wisdom features. E. Osty, for whom purity from the v. 24 has a metaphysical meaning, is also inclined to do so. Following the stoic philosophy, it defines the lack of confusion in the nature of wisdom, its simplicity of substance. Cf. E. Osty, Le livre de la Sagesse, 59; cf. also M. Gilbert, Mąrość Salomona, vol. 1, 85; C. Larcher, Études, 374.

${ }^{37}$ Cf. C. Larcher, Le livre de la Sagesse, vol. 2, 495-496.

38 Although the content of verses 25-26 connect Wisdom even closer with God

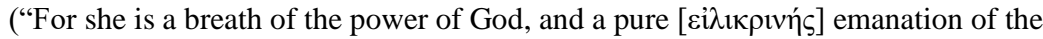
glory of the Almighty; therefore nothing defiled gains entrance into her. For she is a reflection of eternal light, a spotless mirror of the working of God, and an image of his goodness"), these verses are in a way an extension of verse 24, which gives direction to the thought. Cf. M. Gilbert, "L'éloge de la Sagesse (Sg 7-9)," in: La Sagesse et Jésus-Christ (Cahiers Evangiles 32), Paris 1980, 33-36. 
the author emphasises the closeness of Wisdom to God. ${ }^{39}$ It is therefore, on the one hand, existential, ontological purity, and on the other hand, holiness - perfect moral purity.

However, must the gradation presented and the emphasis placed on Sophia's exceptional status in v. 24 contradict the possibility of interpreting the second of the three adjectives from the end of the $\mathrm{v}$. 23 with regard to human souls? It seems not, as C. Larcher points out in his commentary. ${ }^{40}$ It is very likely that $\kappa \alpha \theta \alpha \rho \tilde{\omega} v$ will be read as a sine qua non condition for the being penetrated by Wisdom, which would be testified to in v. 25b: "therefore nothing defiled gains entrance into her."

However, there is no doubt that the word $\kappa \alpha \theta \alpha \rho$ ó $\varsigma$ from v. 23 and 24 serves to highlight in the first place the characteristics of Wisdom as pure - the highest and closest to God. Later, however, (with the context of v. 27 and v. 25b) it also directs the reader's thoughts towards the man whom Wisdom penetrates and in whom it awakens (shapes) God's friend and a prophet.

Another question arises, perhaps the most important for the interpretation of the pericope in question from the point of view of the words with the $\kappa \alpha \theta \alpha \rho$ root: is it legitimate to understand this text as follows - Wisdom gives her qualities (including purity) to those on whom she descends?

\subsection{Wisdom imparting its purity to man}

The original meaning of the word penetrate ( $\chi \omega \rho \varepsilon ́ \omega ;$ v. 23 ) would indicate the impossibility of interpreting the text as Wisdom's imparting her own qualities to man. It is derived from Stoic philosophy and would mean here "the permeation of one substance by another without losing or confusing its specific properties." ${ }^{41} \mathrm{On}$ the one hand, such an understanding once again stresses the uncompromising superiority of Wisdom, but on the other hand, it makes it impossible to change the characteristics of man and therefore there can be no question of passing on purity. It must not

\footnotetext{
${ }^{39}$ Cf. C. Larcher, Études, 376; B. Poniży, Księga Mądrości. Od egzegezy, 42.

${ }^{40}$ Cf. C. Larcher, Le livre de la Sagesse, vol. 2, 492.

${ }^{41}$ Cf. ibid., 491.
} 
be forgotten, however, that the author, having achieved his first objective - to acknowledge Wisdom as something ultimate - goes on and shows Sophia as descending and making people friends of God. Thus, it seems that the author of the book, while remaining within his cultural context and drawing on it, does not stop at the Stoic meaning of the word "penetrate." Wisdom descends, penetrates and inhabits the pure souls to become the inner principle of man's moral and religious life ${ }^{42}$ - i.e. "to make people the friends of God" (v. 27). Wisdom acts in man as a force, a presence, a light - a moral force, a sanctifying presence and a teaching light. In particular, what can also be read from the wider context of the book, is that the latter means the transmission of Revelation (the mention of the prophets in v. 27), which has become a part of the people of Israel (recalling the "generations"; also in v. 27), although Wisdom is also attributed with any other knowledge, including that of science in the sense of the word prevalent at the time (cf. Wis 7:17-21). ${ }^{43}$ It seems essential here to return to the links between wisdom and purity in the Phedo mentioned in the lexicographic analysis. It is possible that the idea of purification through wisdom, present in Plato, was reworked by the sage, the author of the book, in the spirit of Old Testament theology - Wisdom, the most pure and residing with God, purifies man and makes him a friend of the Lord.

It can therefore clearly be seen that the author of the Book of Wisdom does not focus on Sophia's ability to convey its purity in the sense of immateriality and absolute superiority to other beings, i.e. ontological purity. Instead, we can say that he is directing his attention to passing on an aspect of moral purity, which is the one that is closely linked to holiness.

Reading the pericope of Wis 7:22-28 in the broader context of the whole book and having in mind the connotation of purity and observance of the Law, as well as the reference of v. 27 to the prophets, the idea becomes apparent that perhaps the sage does not

\footnotetext{
${ }^{42}$ Cf. idem, Études, 393.

${ }^{43}$ The text of Wis 7:17-21 contains, to quote B. Poniży, "an inventory of what belonged to general education in Hellenism". The knowledge of cosmology, physics, astronomy, chronology, zoology, demonology, human thinking, botany, pharmacology is mentioned." Cf. C. Larcher, Études, 393-395; B. Poniży, "Pojęcia hellenistyczne w Księdze Mądrości,” Poznańskie Studia Teologiczne 2002, 84-85.
} 
mean Wisdom imparting directly to man her own moral purity, but her doing so through the Law, which would correspond to the way of thinking of the Jewish author. This would highlight the Law, as well as the idea of Israel's election. Both aspects are very important in the overall message of the book, which makes such an interpretation legitimate.

\section{4. "The paradox of purity" and an attempt to solve it}

However, when trying to understand Wis 7:22-28 in terms of purity, a kind of contradiction or rather something we could call the "paradox of purity" appears before the reader's eyes. It has been noted that Wisdom can be understood as a source of purity: particularly with regard to the Law. Thanks to it, it is possible to know the commandments of the Decalogue, the observance of which gives righteousness and purity; the "friend of God" according to the measure of the Old Testament is precisely the one who fulfils the Law, observes the commandments - and these can be known thanks to Wisdom. ${ }^{44}$ In this way, Wisdom is also a prerequisite for maintaining intimacy with God (see v. 28: "for God loves nothing so much as the man who lives with wisdom"). On the other hand, there is the conviction that man must already be pure in order for Sophia to be able to influence him (cf. the presented above interpretation of the penetration of pure spirits from v. 23 in the context of v. 27; as well as w. 25b: "Nothing defiled gains entrance into her"). ${ }^{45}$

How can we get out of this paradox? Does the author of the Book of Wisdom really contradict himself, or does he simply not reveal all his theological thought in Wis 7:22-28, in the light of which the "paradox of purity" would be understandable? In order to answer

\footnotetext{
${ }^{44}$ Cf. M. Gilbert, "Volonté de Dieu et don de la Sagesse (Sg 9,17s.)," in: Nouvelle Revue Théologique 1971, 151-154, after: http://www.nrt.be/docs/articles/1971/932/1300-Volont\%C3\%A9+de+Dieu+et+don+de+la+Sagesse+\%28Sg+9\% 2C17+s.\%29.pdf (access 03.09.2015).

${ }^{45} \mathrm{It}$ is worth noting here once again the link between Wisdom and God - purity as a symbol of God's own action - which makes the need to be pure, a priori in relation to contact with Sofia, even more evident. Cf. M. Gilbert, Mądrość Salomona, vol. 1,51 .
} 
these questions, two issues need to be raised: man's request for Wisdom and the image of Israel.

The former is probably shown most fully in the text of the $9^{\text {th }}$ chapter of the Book of Wisdom, where Pseudo-Salomon (as the author of the text is sometimes called ${ }^{46}$ ) directs his thoughts towards God, asking Him for the gift of Wisdom. This pericope is a summary of previous chapters (including Wis 7:22-28) in which Wisdom is described and praised. For the attempt to solve the outlined contradiction, it is not important here to go into the details, but only to stress that the author presents a condition different than purity for receiving Sophia. Maurice Gilbert writes in one of his articles: "The source of Solomon's wisdom is an intense prayer to the Lord." 7 However, in another place, the same author points out, referring to the peculiar framework of the text of the prayer for Wisdom, ${ }^{48}$ that the "creation" and "salvation" (being saved) present there form a "total reality, anticipating the man who formulates prayer." 49 So, in developing this thought, should we not be tempted to say that without Wisdom, without its influence on man, as it is she who assists God and "knows His works" (Wis 9:2; 9:9) and she herself is presented as the one who saves man (Wis 9:18), is it impossible to pray for her? This does not seem to be a mistake. So in order to be able to pray for Wisdom, and to receive it as a result of prayer, an $a$ priori action of Sophia on man is necessary.

It would be possible to say already here, that the same holds true for purity - it is the a priori gift of Wisdom to man: man is already pure before Wisdom sanctifies (purifies) him even more. The context of the book, however, makes us ask whether this applies to every human being. In addition to the often stressed link between purity and the Law, the very prayer for Wisdom, the content of which makes an important contribution to the problem, points out certain interpretative directions. We read in its text: "I am thy slave and the son of thy maidservant" (9:5a) and further on: "Thou hast

\footnotetext{
${ }^{46}$ Cf. for example: B. Poniży, "Przesłanie Mdr 19, podsumowującego rozdziału Księgi Mądrości,” Collectanea Theologica 77 (2007) no. 1, 5-28.

${ }^{47}$ M. Gilbert, Mądrość Salomona, vol. 1, 49; cf. also ibid., 51.

${ }^{48}$ Precisely, it is about verses $9.2 \mathrm{a}$ and $9.18 \mathrm{c}$.

49 Ibid., 89.
} 
chosen me to be king of thy people and to be judge over thy sons and daughters" (9:7) and more: "I shall judge thy people justly" (9:12b). Drawing attention here to the people of Israel is not accidental; on the contrary, it corresponds to a strict connotation of purity with justice and observance of the Law.

In this way the reader's attention is directly drawn to the idea of being elected by God. This seems to be confirmed very clearly also in Chapter 10 and subsequent ones of the Book of Wisdom, where the wise man - giving an example of the action of "Wisdom in History" (such a title is given to this section in the Polish translation of BT) - describes the history of the Patriarchs of the Chosen People and the episode associated with the Egyptian exodus. Those elected by God enjoy Wisdom's care, which is confirmed and concluded by the last verse of the book: For in everything, O Lord, thou hast exalted and glorified thy people; and thou hast not neglected to help them at all times and in all places" (Wis 19:22).

Based on the further context of the Wis 7:22-28 pericope, it is therefore possible to indicate a solution to the observed "paradox of purity." This solution lies in recognizing the a priori action of Wisdom towards man, which is closely linked to the idea of being chosen by God. This choice makes man capable or perhaps: equipped with what is necessary to become a pure, righteous man. In this way, the recognition of God's anticipatory action and His Wisdom does not exempt one from the obligation to pursue purity, as is evident in the context of Wis 9. At the same time, the emphasis here inevitably falls on the Law, which is all the more evident because the Book of Wisdom clearly indicates the choice of Israel, which finds its climax in the granting of the Law on Mount Sinai (the Sinai covenant). However, it would be a serious mistake not to mention, at least in the final sentences of this article, that the text of the book contains numerous features that would indicate an attempt to universalise the Old Testament theology. ${ }^{50}$

\footnotetext{
${ }^{50}$ One could mention here, for example, the content of Wis 13:1-9, where there is a reference to the knowledge of God from created things, i.e. natural cognition, and an antonomasia in the allegory of patriarchs from Chapter 10, where by omitting the names of specific people from the biblical history of the Chosen People, the author of the Book of Wisdom seems to enable a more complete reception of the content also by people who are not rooted in Old Testament culture and history.
} 


\section{Conclusions}

The present article aimed at interpreting a fragment of Wis 7:22-28 in the key of purity - a Greek word with the $\kappa \alpha \theta \alpha \rho$ root which appears twice in it. The basic research problem is an attempt to find a solution to the contradiction observed in the text (called the "paradox of purity"), which can be summarised as follows: purity is shown as a condition and at the same time an effect of granting Wisdom to man.

Since a solid exegesis was not possible without any reference to the religious and cultural context of the time, the first part was entirely devoted to analysing the meaning of the words $\kappa \alpha \theta \alpha \rho$ ó $\varsigma$

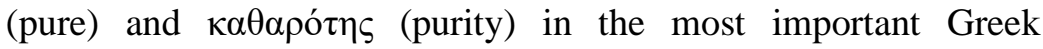
dictionaries and lexicons available. The result of the research is, on the one hand, a strong biblical connection between purity and justice as well as observance of the Law, and on the other hand, an emphasis on the importance of the moral meaning of purity linked to the concept of holiness, which prevails over ritualistic meaning - both in Old Testament texts and in extra-biblical literature.

Transferring these observations to the analysis of Wis 7:22-28, attention was first drawn to the reference object of the adjective $\kappa \alpha \theta \alpha \rho$ ó (pure; Wis 7:23). It was found that the concept of spirits, which this adjective describes, may also include a human being (as a being having a soul). This statement was related to the meaning

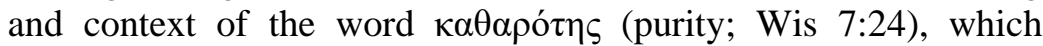
showed a clear gradation of beings in which Wisdom exceeds all others due to her purity. Purity as Sophia's superior principle not only elevates her above other beings, but also places her in close proximity to God - by connotation with holiness understood here as moral purity. This purity, being an attribute of God, becomes in the description of the author of the book proper to Wisdom itself.

Referring these two fundamental thoughts to the rest of this pericope, particularly verse 27 , the question was posed whether and how Wisdom can impart its purity to man. The positive answer to the first part of the question, supported by the observations from the lexicographic analysis, led to the thesis that, according to Wis 7:27, the transmission of moral purity is possible by way of the Law. This is how one can understand "entering into holy souls" and "making 
[people] friends of God" (v. 27). These elements, juxtaposed with the fragments of the pericopes indicating the impossibility of contact between Wisdom and what is defiled, have led to the formulation of a specific "paradox of purity." It consists in the fact that having purity is treated as a condition and, at the same time, an effect of Wisdom being imparted to man. An attempt to solve this contradiction was based on reference to the context following Wis 7:22-28 - in particular to the prayer for Wisdom in Chapter 9 and the catalogue of patriarchs and the description of the exodus from Egypt as a testimony to the idea of choice in Chapter 10. In this way, the research undertaken in the article is summarised in the formulation of the claim that Wisdom must act a priori in relation to the efforts of a man who wants to achieve purity. At the same time, however, Sophia's a priori influence on a human person does not relieve him/her from making the effort to achieve purity.

The issue that suggests itself, which however due to its not being part of the main topic, was not addressed here, is the question of the universality or exclusivity of God's choice: who does God include in His a priori act of preparation for the adoption of Wisdom? This is a vast subject, but one worth exploring in greater depth. Another aspect that has only been mentioned in passing in the first part of the article, and to which perhaps it is worthwhile to devote more space and time, is the reference of the thought of the author of the Book of Wisdom to the Plato's Phaedo, which, on the basis of a broad outline, seems to be of considerable importance as the ideological background to the text.

\section{Bibliography}

\section{Sources}

Authorized Version Apocrypha, 1769 Blayney Edition (KJA), Oxford 1769, BibleWorks, v. 9.

Biblia Tysiąclecia: Pismo Święte Starego i Nowego Testamentu w przekładzie z języków oryginalnych (BT), ed. 4, Poznań 1983.

Biblia Tysiąclecia: Pismo Święte Starego i Nowego Testamentu w przekładzie z języków oryginalnych (BT), ed. 5, Poznań 1999. 
Demosthenes, The Third Philippics, Greek text and English translation after: http://www.perseus.tufts.edu/ (access 12.12.2020).

The Letter of Pseudo-Aristeas, Greek text after: http://www.ccel.org /ccel/swete/greekot.vii.ii.html (access 08.09.2015).

New Revised Standard Version Bible (NRS), New York 1989, BibleWorks, v. 9.

Plato, Phaedo, Greek text and English translation after: http://www.perseus.tufts.edu/ (access 12.12.2020).

Rahlfs, A., Septuaginta: Id est Vetus Testamentum iuxta LXX interpretes edidit Alfred Rahlfs (LXT), Stuttgart 1935, BibleWorks, v. 9.

Theognis of Megara, The Elegiac Poems, Greek text and English translation after: http://www.perseus.tufts.edu/ (access 12.12.2020).

\section{Subject literature, dictionaries, other}

Freedman, D.N. (ed.), Anchor Bible Dictionary (AB), vol. 6, New York 1992.

Gilbert, M., "L'éloge de la Sagesse (Sg 7-9)," in: La Sagesse et JésusChrist (Cahiers Evangiles 32), Paris 1980, 33-36.

Gilbert, M., Mądrość Salomona, vol. 1, transl. S. Kobiałka, Kraków 2002. (= M. Gilbert, La Sapienza di Salomone, Roma 1995).

Gilbert, M., "Volonté de Dieu et don de la Sagesse (Sg 9,17s.)", in: Nouvelle Revue Théologique 1971, 145-166, after: http://www.nrt.be/ docs/articles/1971/93-2/1300-Volont\%C3\%A9+de+Dieu+et+don+de + la+Sagesse+\%28Sg+9\%2C17+s.\%29.pdf (access 03.09.2015).

Grabbe, L.L., Wisdom of Solomon, Sheffield 1997.

Kittel, G., Friedrich G., Bromiley G.W., Theological Dictionary of the New Testament. Abridged (TDNT), Grand Rapids 1985.

Lambdin, T.O., Wprowadzenie do hebrajskiego biblijnego, Lublin 2012.

Larcher, C., Études su le livre de la Sagesse, Paris 1969.

Larcher, C., Le livre de la Sagesse ou la Sagesse de Salomon, vol. 2, Paris 1984.

Liddell, H.G., Scott, R., Jones, H.S., McKenzie, R., A Greek-English Lexicon: With a Revised Supplement (LSJ), 9th ed., Oxford 1996.

Lust, J., Eynikel, E., Hauspie, K., Greek-English Lexicon of the Septuagint, Revised ed. (LEH), Stuttgart 2003, BibleWorks, v. 9.

Osty, E., Le livre de la Sagesse (La Sainte Bible), Paris 1957.

Pirot, L., Robert, A. (eds.), Dictionnaire de la Bible, vol. 5, Paris 1957.

Poniży, B., Księga Mądrości. Od egzegezy do teologii, Poznań 2000.

Poniży, B., Księga Mądrości. Wstęp - przektad z oryginatu - komentarz (Nowy Komentarz Biblijny ST XX), Częstochowa 2012. 
Poniży, B., "Pojęcia hellenistyczne w Księdze Mądrości," Poznańskie Studia Teologiczne 2002, 73-85.

Poniży, B., "Przesłanie Mdr 19, podsumowującego rozdziału Księgi Mądrości," Collectanea Theologica 77 (2007) no. 1, 5-28.

Winston, D., The Wisdom of Solomon. A New Translation with Introduction and Commentary (Anchor Bible 43), Garden City 1979. Wojciechowski, M., "List Pseudo-Arysteasza," Studia Theologica Varsaviensia 40 (2002) no. 1, 121-167. 